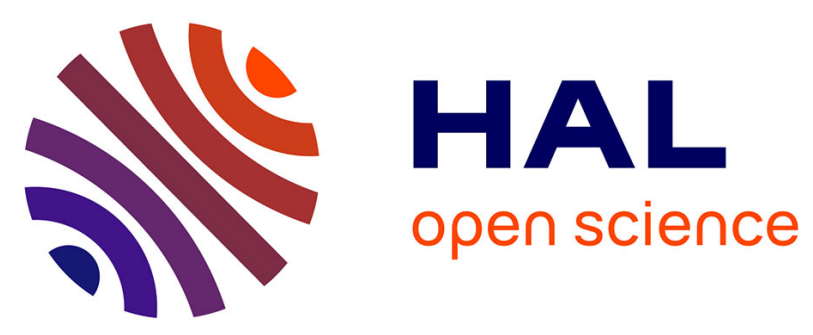

\title{
Why Have Bank Interest Margins Been so High in Indonesia Since the 1997/1998 Financial Crisis?
}

Irwan Trinugroho, Agusman Agusman, Amine Tarazi

\section{To cite this version:}

Irwan Trinugroho, Agusman Agusman, Amine Tarazi. Why Have Bank Interest Margins Been so High in Indonesia Since the 1997/1998 Financial Crisis?. 2012. hal-00916531

\section{HAL Id: hal-00916531 \\ https://hal-unilim.archives-ouvertes.fr/hal-00916531}

Preprint submitted on 10 Dec 2013

HAL is a multi-disciplinary open access archive for the deposit and dissemination of scientific research documents, whether they are published or not. The documents may come from teaching and research institutions in France or abroad, or from public or private research centers.
L'archive ouverte pluridisciplinaire HAL, est destinée au dépôt et à la diffusion de documents scientifiques de niveau recherche, publiés ou non, émanant des établissements d'enseignement et de recherche français ou étrangers, des laboratoires publics ou privés. 


\title{
Why Have Bank Interest Margins Been so High in Indonesia since the 1997/1998 Financial Crisis?
}

\author{
Irwan Trinugroho $^{\mathrm{a}}$, Agusman Agusman ${ }^{\mathrm{b1}}$, Amine Tarazi ${ }^{\mathrm{a}}$ \\ ${ }^{a}$ Université de Limoges, LAPE, 5 rue Félix Eboué, 87031 Limoges Cedex, France \\ ${ }^{b}$ Bank Indonesia, Jl. M. H. Thamrin, No.2, Jakarta 10350, Indonesia
}

This draft: August 8, 2012

Please do not quote without the permission of the authors

\begin{abstract}
We investigate the determinants of net interest margins of Indonesian banks after the 1997/1998 financial crisis. Using data for 93 Indonesian banks over the 2001-2009 period, we estimate an econometric model using a pooled regression as well as static and dynamic panel regressions. Our results confirm that the structure of loan portfolios matters in the determination of interest margins. Operating costs, market power, risk aversion and liquidity risk have positive impacts on interest margins, while credit risk and cost to income ratio are negatively associated with margins. Our results also corroborate the loss leader hypothesis on cross-subsidization between traditional interest activities and non-interest activities. Stateowned banks set higher interest margins than other banks, while margins are lower for large banks and for foreign banks.
\end{abstract}

JEL Classification: G21, G28, G32

Keywords: Bank interest margins, Financial intermediation, Small scale loans, Indonesia

\footnotetext{
${ }^{1}$ The views expressed in this paper are the authors' only and do not necessarily reflect those of Bank Indonesia
} 


\section{Introduction}

It is widely known that the average net interest margin, the difference between interest income and expenses divided by interest-earning assets, of Indonesian banks is relatively higher than those observed in other countries particularly in the East Asia region (Rosengard and Prasetyantoko, 2011). A number of cross country studies point out this fact. DemirgüçKunt and Huizinga (1998) show that the average margins of Indonesian banks for the 19881995 period was 3.6\%, higher than those of neighboring countries such as Singapore (2.2\%), and Malaysia (2.7\%). Using data after the 1997/1998 financial crisis from 1999 to 2008, López-Espinosa et al. (2011) show that, in Indonesia, average bank interest margins (4.85\%) were much higher than, for example, the average interest margins of Japanese banks (1.92\%). Recently, Lin et al. (2012) have indicated that with a value of $6.36 \%$ the average bank margin of Indonesian banks over the 1997-2005 period, was the highest compared to other Asian countries in their sample ${ }^{2}$. Their work also shows that the interest margin of Indonesian banks is significantly higher after the $1997 / 1998$ crisis than before ${ }^{3}$.

The present paper extends the literature on the determinants of net interest margins by studying Indonesian banks which have experienced a problem of persistently high net interest margins since the 1997/1998 financial crisis. We hypothesize that the persistence of high interest margins in Indonesia is affected by a set of simultaneous factors which are the structure of loan portfolios, the degree of competition, the level of income diversification, cost efficiency, bank size as well as credit risk and liquidity risk. We also assume that net interest margins are influenced by bank ownership characteristics. To our knowledge, this paper is the first that comprehensively studies the determinants of net interest margins in Indonesia after the crisis. We incorporate two unique loan portfolio components, small scale loans and property loans, as factors explaining interest margins which contextually matter in Indonesia. Studying interest margins with regard to the ownership and governance characteristics of banks is also important. Using pooled regression techniques as well as static and dynamic panel regressions, we find evidence that the structure of loan portfolios do matter in the determination of interest margins. Specifically, small scale loans contribute to increase bank margins, whereas housing (property) loans tend to reduce interest margins. Also, operating costs, market power, risk aversion and liquidity risk significantly and

\footnotetext{
${ }^{2}$ We conduct our own computations using data from BankScope for banks in 9 East Asia countries from 2005 to 2009. The average margin of Indonesian banks is $5.7 \%$ far above the $3.03 \%$ on average for the 8 other countries.

${ }^{3}$ López-Espinosa et al. (2011) also show that average interest margins of Indonesian banks have increased over their sample period.
} 
positively affect margins, while credit risk and cost to income ratio are negatively associated with margins. Our results also corroborate the loss leader hypothesis on cross-subsidization of lending and non-interest activities. Furthermore, state-owned banks have higher margins than other banks, while foreign banks and large banks set lower margins.

The remainder of this paper is organized as follows. Section 2 reviews previous work on related issues. In section 3, we provide some background on Indonesian banking. In Section 4, we describe our data, variables, and empirical model. Section 5 reports the results and robustness checks. Section 6 concludes our findings and provides policy implications.

\section{Literature Review}

As financial intermediary institutions, banks collect deposits from surplus spending units with an interest cost and distribute it to deficit spending units by charging an interest rate. Although high interest margins are associated with inefficiency (Drakos, 2003; Beck and Hesse, 2009; López-Espinosa et al., 2011), some studies, however, use interest margins as a measure of bank profitability (e.g. Chen and Liao, 2011). The issue of how banks set their interest margin has been extensively studied in the literature. In a seminal paper, Ho and Saunders (1981) introduce the dealership model in which banks perform as a risk-averse intermediary between the demanders and suppliers of funds. Their model posits that positive interest margins will prevail as long as banks are risk-averse agents and face uncertainty even in a highly competitive market. They conclude that a bank's interest margin is determined by four factors: the degree of managerial risk aversion, the size of transactions, market structure, and the variance of the market interest rate. Many empirical studies have expanded and examined the dealership model using cross-country data or by focusing on a single country in the context of developed and developing countries (e.g. Angbazo, 1997; Saunders and Schumacher, 2000; Maudos and de Guevara, 2004; Carbó and Rodriguez, 2007; Hawtrey and Liang, 2008; Maudos and Solís, 2009; Poghosyan, 2010; Fungáčová and Poghosyan, 2011; Lin et al., 2012). The literature has also provided theoretical microeconomic approaches to optimal interest margin setting (Allen, 1988; Angbazo, 1997; Maudos and de Guevara, 2004; Maudos and Solís, 2009). Another comprehensive study on the determinants of interest margins is proposed by Beck and Hesse (2009) enlightening four major perspectives which determine interest margins and spread: i) risk-based view concerning the compensation for the riskiness of loans, ii) small financial system focuses on the fixed cost component of financial service provision and the resulting scale economies, iii) market structure matters for competitiveness and ownership structure of the banking market, iv) macroeconomic view 
reveals that spreads and margins are affected by monetary and exchange rate policies as well as economic cycles.

From a risk-based perspective and in line with previous studies, Beck and Hesse (2009) argue that higher risk in bank lending contributes to positively affect margins. Under this view, banks will charge a higher risk premium for riskier loans. Subsequently, the level of risk compensation may depend on the structure of the loan portfolio. More specifically, in the case of a developing country such as Uganda, Beck and Hesse (2009) find that sectoral loan portfolio composition of banks influences the variation of margins ${ }^{4}$. In the present paper, we consider two types of lending which may significantly contribute to determine interest margins. Firstly, like in other developing countries, bank lending to small medium enterprises (SMEs) is prevalent in Indonesian banks especially in domestic banks. Loans to SMEs may require a higher risk premium because SMEs are more financially constrained than large firms and they are relatively opaque (de la Torre et al., 2010) due to weaker or non-existent accounting standards (Behr et al., 2011). Moreover, lending to these firms is typically costly in the context of Indonesia (Agung et al., 2001). Secondly, we consider that the proportion of housing (property) loans could affect the setting of interest margins. As a large market, Indonesia has been undergoing consumption-driven economic growth. One of the drivers is the growth of housing demand (Hoek-Smit, 2005) which subsequently leads to escalate the demand of housing loans. This type of lending is considered as less risky because for each loan banks hold the certificate of ownership as collateral with a value that will increase over time under normal conditions. Moreover, the policy of the Government of Indonesia to widen the access to housing finance for the poor imposes banks to charge a lower rate.

Ho and Saunders (1981) argue that banks facing relatively inelastic demand and supply functions can exercise their monopoly power to set a greater margin. A number of empirical studies have examined how market structure and banking competitive conditions impact on interest margins ${ }^{5}$. Maudos and de Guevara (2004) find a positive effect of bank market power estimated by the Lerner index on interest margins in the banking sectors of the European Union. Claeys and Vennet (2008) find that a higher interest margin is associated with a higher concentration of the banking industry in Central and Eastern European

\footnotetext{
${ }^{4}$ Using data of Ugandan banking, they include a number of sectors which are agriculture, mining, manufacturing, trade, transportation, construction, and other services.

5 There are two widely used methods to measure market structure and its impact on bank margins in the literature which are the Herfindahl Hirschman Index (HHI) and the Lerner index. However, these two measures do not necessarily reflect the same dimension. HHI measures the concentration of the industry, while the Lerner index reflects the degree of competition as it measures the ability of a bank to influence the price of products and is therefore directly linked to competition (Weill, 2011).
} 
countries. Using data of Mexican banks, Maudos and Solís (2009) find that banks with greater market power, measured by a Lerner index, have higher interest margins. Following the studies of Maudos and de Guevara (2004) and Maudos and Solís (2009), we use the Lerner index to represent the degree of competition. Banks having a greater market power are supposed to set higher interest margins ${ }^{6}$.

All around the world banks have now become more diversified in their revenues' sources. Deregulation and technological changes have triggered the development of noninterest activities and reduced the importance of traditional intermediation activities (Lepetit et al., 2008; Elsas et al., 2010). Lepetit et al. (2008) test the loss leader hypothesis contending that the link between diversification in bank activities and interest margins could be negative as banks might be charging a lower lending rate to attract new customers and to build longterm relationship enabling the sales of services and higher gains from non-interest income activities. They empirically test this hypothesis in the context of European banks. Similarly, Maudos and Solís (2009) find that diversified banks, i.e. with a higher degree of non-interest income, have lower interest margins. Although income diversification is also widespread in Indonesian banks, the dependency on traditional banking activities is still prevalent as well ${ }^{7}$.

We also take into account the efficiency in the production process, bank size, risk aversion, credit risk and liquidity risk to explain the persistence of high interest margins in Indonesia. We follow the studies of Maudos and de Guevara (2004); Beck and Hesse (2009); Maudos and Solís (2009); Fungáčová and Poghosyan (2011) to include operating (overhead) costs in the determination of interest margins. Maudos and de Guevara (2004) extend the dealership model by including operating costs to represent how efficient banks are in their production process. The higher the ratio of operating costs to total assets, the higher the interest margins banks set. The other proxy of efficiency is the cost to income ratio which also measures the quality of bank management as argued by Maudos and Solís (2009) as this ratio reflects a spent cost for a selected asset. They find that this ratio has a negative effect on interest margins. Bank size is also included. Some empirical studies find that large banks have lower margins because these banks may reach economies of scale enabling them to decrease their margins (Fungáčová and Poghosyan, 2011) and they tend to grow in loans markets with low margins (Lopez-Espinosa et al., 2011). Beck and Hesse (2009) also argue that smaller banks may encounter higher costs and therefore set higher margins. We

\footnotetext{
${ }^{6}$ We report in the robustness check's section the results obtained with HHI instead of the Lerner index.

${ }^{7}$ In this paper, we show that the average diversification index is only 0.16 indicating that as a whole, Indonesian banks are less diversified than in other countries.
} 
incorporate the ratio of equity to total assets which is considered to represent the degree of bank risk aversion (Maudos and Solís, 2009; Poghosyan, 2010). In the dealership model, Ho and Saunders (1981) explain that higher managerial risk aversion will increase interest margins. We follow a number of previous studies which include credit risk as a determinant of interest margins. Regarding the effect of credit risk on bank margins, there are two competing arguments. On the one hand, banks facing higher credit risk will charge a higher risk premium on the loans they grant (Angbazo, 1997; Maudos and de Guevara, 2004; LópezEspinosa et al., 2011). On the other hand, as argued by Fungáčová and Poghosyan (2011) risky banks could be punished by depositors in the form of a higher interest rate required on deposits implying that margins should be lower for these banks. Another factor that we consider to influence margins is liquidity risk. López-Espinosa et al. (2011) contend that the higher opportunity cost of holding reserves as a result of higher liquid assets would decrease net interest margins. Similar results are also found in other studies (Maudos and de Guevara, 2004; Chen and Liao, 2011).

We also question whether bank interest margins differ across ownership types. Firstly, we consider the interest margins of state-owned (government) banks. The role of state-owned banks in a banking system has been studied in several perspectives, particularly in the context of developing countries in which the behaviors of these banks matter more (Micco et al., 2007). According to social or development theory of public enterprises, these banks are often inefficient because they play a specific role as development agencies. Sometimes they are assigned to fund unprofitable government projects. Additionally, labor surplus could also be a form of policy burden that should be borne by these banks to help government reduce unemployment. Such development roles of these banks may lead them to be more costly and in turn set higher interest margins. Another possible difference between state-owned banks and private banks regarding margin setting could stem from implicit guarantees and too-bigto-fail considerations. Depositors may perceive state-owned banks as less risky because they believe that the government will rescue them if they face financial problems which mean that these banks are perceived to have a larger implicit guarantee (Mondschean and Opiela, 1999). Moreover, given that state-owned banks in Indonesia are mostly large banks, the too-big-tofail dimension should also be considered. These two factors could lead such banks to charge a lower rate on deposits, which ultimately could spread their margins. Secondly, we examine whether the interest margins of foreign banks are different from those of other banks. It is generally argued that foreign banks in emerging countries have positive economic impacts on the host country in terms of resources allocation and higher efficiency (Claessens et al., 
2001). Having better hard information and technology may lead these banks to perform more efficiently than domestic banks.

Few studies examine the role of ownership in the determination of interest margins ${ }^{8}$. Contrary to the common expectation, Drakos (2003), using data of banks in Central and Eastern European Countries (CEECs) and the Former Soviet Union countries (FSU), finds that state-owned banks typically set lower margins. Martinez-Peria and Mody (2004) show that foreign banks in 5 Latin American Countries charge lower interest margins than domestic banks. Poghosyan (2010), by considering the dealership approach, finds that foreign bank participation does not affect interest margins in Central and Eastern European countries. Fungáčová and Poghosyan (2011) find that in Russia, the impact of some interest margins determinants differs across state banks, domestic private banks and foreign banks. Though the results of previous studies on this issue are inconclusive, the unique feature of the Indonesian banking structure is worth be considering in our investigation on the determinants of interest margins.

\section{Indonesian Banking Post-Financial Crisis}

The 1997/1998 financial crisis has led to severe consequences regarding the intermediation function of Indonesian banks. Early after the crisis, the Indonesian banking system experienced a credit crunch phenomenon banks being reluctant to grant new loans ${ }^{9}$. This credit crunch led to a sharp decrease in intermediation as shown by a lower ratio of loans to deposits. Banks then charged a strangling interest rate on loans to cover their intermediation costs. The credit crunch was considered as the factor causing the slower process of Indonesia's economic recovery compared to other Asian countries that have suffered from the crisis such as South Korea and Thailand (Agung et al., 2001). To accelerate the economic recovery, the Government of Indonesia then conducted several policies relying on banks as the locomotive given their importance in the financial system ${ }^{10}$. Thus, the

\footnotetext{
${ }^{8}$ Poghosyan (2010) argues that no theoretical paper has incorporated the role of ownership in the determination of interest margins. Moreover, he denotes that any potential impact of ownership, particularly foreign banks versus domestic banks, have already been accounted for in the dealership model and its extension.

${ }^{9}$ The banks' reluctance to grant loans was considered as the result of the excessive bank lending behavior during the banking deregulation regime which amplified the impact of the financial crisis. Therefore, banks then behaved very carefully in their lending activities. In the aftermath of the crisis, other affected countries in the region such as Malaysia, Thailand, South Korea, and Philippines also faced the credit crunch problem (Ding et al., 1998). Bank credit in Indonesia then continued to grow slowly due to banks being confronted with higher credit risk, capital crunch, and lack of information regarding the quality of borrowers (Agung et al., 2001). In 2001, the average loan to deposit ratio of banks included in our sample was only 54\% (more details are provided in our descriptive statistics' tables 1 and 2).

${ }^{10}$ The capital market and other financial intermediation institutions were still relatively underdeveloped.
} 
government bolstered banks to improve their intermediation activities. Though several improvements in the banking sector have been implemented following the institutional reforms and economic recovery, the problem of high interest margins has been a serious problem in this country. Regulators have paid a greater attention on this issue by issuing a number of regulations to promote healthy competition, to improve market discipline, to boost good governance which expectedly could decrease interest margins and subsequently improve the efficiency of financial intermediation. Moreover, Bank Indonesia recently released a direct regulation on prime lending rate transparency for commercial banks. This regulation is intended to promote the transparency of banking products, including their benefits, costs and risks. At the primary stage, this regulation is addressed for those having assets more than 10 trillion Rupiah.

Like in other developing countries, the existence of micro, small, and medium enterprises (MSMEs) was an important issue in Indonesia ${ }^{11}$ because of their significant contribution to the economy in forms work force and output, high priorities given by the government, and better response to the harmful 1997/1998 economic crisis (Hill, 2001; Hayashi, 2002) even though they faced several problems such as access to capital markets, and lack in technology that made them less competitive than others (Najib et al., 2011). As the importance of MSMEs in the economy, the government encouraged banks to increase the accessibility to financing for MSMEs ${ }^{12}$. In 2001, Bank Indonesia issued a regulation (PBI No: 3/2/PBI/2001) on small scale loans stating that banks were recommended to channel small scale loans in their lending portfolio ${ }^{13}$. Improving access of MSMEs to credit and financing was also highlighted in the implementation plan of the Indonesian Banking Architecture (IBA) ${ }^{14}$.

Following the economic recovery, the Indonesian economy then consistently grew majorly driven by consumption. This fourth most populated country in the world faced an

\footnotetext{
11 The Indonesia Statistics Bureau released data presenting that in 2007, $99.99 \%$ of business units are micro, small, and medium enterprises and they account for $97.3 \%$ of the total workforce in Indonesia (Statistics of Micro, Small and Medium Enterprises 2007-2008).

${ }^{12}$ Agung et al. (2001) reveal that lending to SMEs in Indonesia was relatively low risk, however, banks were still reluctant to release loans to SMEs due to the fact that loans to these firms were very costly and because banks lacked experience in dealing with SMEs. Wattanapruttipaisan (2003) explains the factors causing the unsuccessful small and medium enterprises (SMEs) financing in ASEAN countries, including Indonesia, after the financial crisis that come from demand and supply sides. In the supply side, banks were reluctant to channel loans to SMEs because they would be the major debtor that looks risky even though they could charge a high risk premium.

${ }^{13}$ This regulation defined small scale loan as a bank lending to borrowers for an investment and/or working capital (productive purposes) up to 500 million Rupiah.

${ }^{14}$ In 2004, the government introduced a concept of Indonesian Banking Architecture (IBA), a road map of the Indonesian banking sector which would be implemented gradually.
} 
escalating housing demand in line with the growth of its population which was one of the main growth drivers. Hoek-Smit (2005) points out that the demand for new housing in Indonesia is more than 800,000 units per year (3.5 to $3.75 \%$ ) which lead the growth in housing (mortgage) loans to exceed growth in other types of credit. The government released policies to ease the access to housing loans for the poor to reduce the number of homeless people and as one of the poverty alleviation programs. The Ministry of Public Housing then issued a regulation on the subsidy of housing loans for the poor in form of a lower-fixed interest rate.

Indonesian banking is featured by a number of state-owned banks which are distinguished based on which government controls the banks. Regional development banks are owned by regional (provincial and district) governments, while state-owned banks are controlled by the central government ${ }^{15}$. As public enterprises, these banks are subject to government policies. However, they also benefit from funding under the form of deposits particularly from small depositors. Two aspects may arise regarding the intermediation cost, i) these banks could charge a lower rate for deposits, ii) the inefficiency of these banks could increase the overhead costs. Therefore the interest margins of state-owned banks could be higher than those of other banks. Another issue regarding bank ownership structure is the foreign banks' participation in this industry ${ }^{16}$. In principle, foreign banks' presence should benefit the domestic market since they have a better technology that could lead them to perform more efficiently and therefore contribute to lower the cost of intermediation.

\section{Data, Variables, and Empirical Model}

This study aims to investigate the factors behind the persistence of high interest margins in Indonesian banking after the 1997/1998 financial crisis. We hypothesize that several factors play a role in explaining the interest margins of Indonesian banks spreading from the structure of loan portfolios, the degree of competition, the level of income diversification, cost efficiency, bank size, risk aversion, credit risk, liquidity risk and ownership structure.

\footnotetext{
${ }^{15}$ Four state-owned banks in our sample are publicly traded banks. The government, however, maintains its majority ownership.

${ }^{16}$ Hamada (2003) shows that foreign banks' presence in Indonesia started in 1968. However, the number of foreign banks was stable until the deregulation of the Indonesian banking sector in 1988 which then doubled the number of foreign banks.
} 


\subsection{Data and Sample}

We use yearly bank-level data for the 2001-2009 period. Annual banks' financial reports (balance sheets and income statements) come from Bank Indonesia and Ekofin Konsultindo. Data on the proportion of small scale loans and the proportion of property loans are reported by banks in the additional information of their financial reports. Our sample covers 93 commercial banks resulting in 617 bank-year observations. We end up with an unbalanced panel because we exclude banks exhibiting negative equity value, incomplete data for some variables and a number of outliers ${ }^{17}$.

\subsection{Variables}

\subsubsection{Dependent variable}

\section{- Net interest margins}

The dependent variable of this study is the net interest margin (NIM) which is the difference between interest income and interest expenses divided by interest-earning assets.

\subsubsection{Independent variables}

\section{- Loan portfolio}

We use two kinds of lending shares which are the proportion of small scale loans to total loans (SMALL) and the proportion of property (housing) loans to total loans (PROPERTY). A positive sign is expected for the small scale loans because these loans may require a higher risk premium and these loans are costly. The coefficient of property loans is expected to be negative as these loans are less risky. Moreover government policy could reduce the interest rate on these loans.

\section{- Market Power (Degree of competition)}

We use a Lerner index (LERNER) to measure the degree of competition as banks with a higher spread between price and marginal cost could be considered to have a higher degree of monopoly power. Banks having a greater market power are supposed to set a higher interest margins (Maudos and de Guevara, 2004; Maudos and Solís, 2009). Referring to Koetter et al. (2012), Lerner index (LERNER) is the difference between average revenues

\footnotetext{
${ }^{17}$ We need to eliminate banks with a negative value of equity in the computation of the Lerner index. For some variables, especially the non-performing loans ratio, we have some missing data. Finally, we ignore extreme observations (outliers) for all the variables, particularly for our dependent variable (net interest margins), which in total corresponds to excluding around 5\% bank-year observations.
} 
(AR) and marginal costs (MC) divided by average revenues (AR) which can be written as follow:

$\mathrm{LERNER}=(\mathrm{AR}-\mathrm{MC}) / \mathrm{AR}$

To calculate the marginal costs, we employ a translog total cost function which includes three input factors (interest on total borrowed funds, labor cost, and cost of fixed assets), four outputs (loans, other earnings assets, total securities, and off-balance sheet items), total equity, and time trend. The total cost function is estimated using a stochastic frontier analysis (SFA) following the work of Koetter et al. (2012).

A positive sign is expected as banks having a greater market power can set a higher interest margin. In addition, we report the results obtained by considering the Herfindahl Hirschman Index (HHI) instead of the Lerner index as a robustness check.

\section{- Diversification}

We follow the method of Elsas et al. (2010) to measure the degree of bank diversification (DIV). Basically, their diversification index is an adjusted HerfindahlHirschman index. The index ranges from 0 (fully specialized bank) to 0.75 (bank with fully balanced revenue).

The diversification index is defined as:

$\mathrm{DIV}=\left[1-\left[(\mathrm{INT} / \mathrm{REV})^{2}+(\mathrm{COM} / \mathrm{REV})^{2}+(\mathrm{TRAD} / \mathrm{REV})^{2}+(\mathrm{OTHER} / \mathrm{REV})^{2}\right]\right] \times 100$

where INT is the gross interest income, COM is the commission income, TRAD represents the trading revenue, and OTHER is other revenue. The denominator is total revenues (REV).

As argued above, we expect a negative sign for the coefficient of this variable because more diversified banks tend to set a lower interest rate (cross subsidization strategy).

\section{- Efficiency}

First, following the studies of Maudos and de Guevara (2004), Beck and Hesse (2009) and Maudos and Solís (2009), we include the ratio of operating costs to total assets (OVERHEAD) to represent the efficiency of the production process. The higher the operating costs, the higher the interest margin banks will charge. Second, the ratio of cost to gross income (CIR) is also employed to measure the efficiency (quality) of management following 
Maudos and Solís (2009). This ratio reflects how much management spends to obtain a unit of income; therefore, a negative sign is expected for this ratio.

- Bank size

Bank size is measured by the natural logarithm of total assets orthogonalized with equity (ORTHOLNTA) because of their strong correlation following the study of Barry et al. (2011). Large banks are expected to set a lower bank margin due to economies of scale enabling them to decrease their margins (Fungáčová and Poghosyan, 2011). Such banks have been found to grow in loan markets with low margins (López-Espinosa et al., 2011).

\section{- Risk aversion}

The ratio of equity to total assets (EQTA) measures the degree of risk aversion as proposed by Maudos and Solís (2009) and Poghosyan (2010). A higher degree of risk aversion is expected to be associated to a higher interest margin set by the bank.

\section{- Credit Risk}

We measure credit risk using the ratio of non-performing loans to total loans (NPL) following the study of Fungáčová and Poghosyan (2011). There are two competing arguments regarding the relationship between credit risk and margins. On the one hand, banks facing higher credit risk might charge a higher risk premium on their loans (Maudos and de Guevara, 2004) thereby increasing interest margins. On the other hand, as argued by Fungáčová and Poghosyan (2011) depositors might require higher interest rates on their deposits because they feel that the bank is more risky and therefore interest margins could be lower. Hence, the expected sign for credit risk is ambiguous.

\section{- Liquidity Risk}

The ratio of loans to deposits stands for bank liquidity risk (LDR). The higher this ratio, the higher the liquidity risk and the lower the bank holds reserves. As argued by LópezEspinosa et al. (2011), a higher level of liquid assets would decrease net interest margins. We therefore expect a positive sign for the coefficient of LDR.

\section{- State-owned banks}

As explained above, state-owned banks in Indonesia consist of central governmentowned banks and regional development banks. We use a dummy variable (SOB) to identify 
the state-owned banks. These banks are expected to charge a lower rate for deposits because they are perceived as less risky by depositors. Moreover, the development roles of these banks may lead them to be more costly. Therefore a positive sign is expected.

\section{- Foreign banks}

Foreign banks (FOB) in Indonesia consist of branches of foreign banks, subsidiaries of foreign banks, and joint venture banks (Hadad et al., 2011). We use a dummy variable (FOB) to categorize foreign banks. Benefiting from better hard information and technology may lead these banks to perform more efficiently than domestic banks. Accordingly, a negative sign is expected.

\subsubsection{Control variables}

\section{- Listed banks}

Publicly traded banks are supposed to have a better monitoring and efficiency. Therefore, we incorporate a dummy variable for listed banks (LISTED) as a control variable.

\section{- Year dummies}

We include year dummies (YEARS) in all of our regressions to capture time effects which could matter because of time-variant macroeconomic factors as argued by Beck and Hesse (2009).

\subsection{Empirical Model}

To deal with multicolinearity issues, we orthogonalize the proxy of size which is the natural log of total assets with equity. Moreover, because our bank diversification variable is highly correlated with the variable capturing small scale loans as well as bank size, we do not introduce the diversification variable concomitantly to these two variables. Likewise, we do not introduce bank size concurrently with operating costs and the cost to income ratio due to their high correlations.

The specifications of the determinants of interest margins to be estimated are formulated as follows:

$$
\begin{aligned}
\text { NIM }_{i, t}= & \alpha_{0}+\alpha_{1} \text { SMALL }_{i, t}+\alpha_{2} \text { PROPERTY }_{i, t}+\alpha_{3} \text { LERNER }_{i, t}+\alpha_{4} \text { OVERHEAD }_{i, t}+\alpha_{5} \text { CIR }_{i, t}+ \\
& \alpha_{6} \text { EQTA }_{i, t}+\alpha_{7} N P L_{i, t}+\alpha_{8} \text { LDR }_{i, t}+\alpha_{9} \text { SOB }_{i}+\alpha_{10} \text { FOB }_{i}+\alpha_{11} \text { LISTED }_{i, t}+Y_{E A R S}+\varepsilon_{i, t}
\end{aligned}
$$




$$
\begin{aligned}
\text { NIM }_{i, t}= & \alpha_{0}+\alpha_{1} \text { SMALL }_{i, t}+\alpha_{2} \text { PROPERTY }_{i, t}+\alpha_{3} \text { LERNER }_{i, t}+\alpha_{4} \text { ORTHOLNTA }_{i, t}+\alpha_{5} \text { EQTA }_{i, t} \\
& +\alpha_{6} \text { NPL }_{i, t}+\alpha_{7} \text { LDR }_{i, t}+\alpha_{8} \text { SOB }_{i}+\alpha_{9} \text { FOB }_{i}+\alpha_{10} \text { LISTED }_{i, t}+\text { YEARS }+\varepsilon_{i, t}
\end{aligned}
$$

NIM $_{i, t}=\alpha_{0}+\alpha_{1}$ PROPERTY $_{i, t}+\alpha_{2}$ LERNER $_{i, t}+\alpha_{3}$ DIV $_{i, t}+\alpha_{4}$ OVERHEAD $_{i, t}+\alpha_{5}$ CIR $_{i, t}+$

$$
\alpha_{6} E Q T A_{i, t}+\alpha_{7} N P L_{i, t}+\alpha_{8} L D R_{i, t}+\alpha_{9} S O B_{i}+\alpha_{10} F O B_{i}+\alpha_{11} L I S T E D_{i, t}+Y E A R S+\varepsilon_{i, t}
$$

where $i, t$ represent bank and time, respectively. NIM is the net interest margin. SMALL and PROPERTY are the proportion of small scale loans to total loans and the proportion of property (housing) loans to total loans, respectively. LERNER is the Lerner index. DIV is the bank diversification index. OVERHEAD is the ratio of operating costs to total assets, while CIR denotes the cost to income ratio. ORTHOLNTA is the natural logarithm of total assets orthogonalized with equity. EQTA is the ratio of equity to total assets. NPL is the ratio of non-performing loans to total loans. LDR stands for the loans to deposits ratio. SOB is a dummy taking value 1 for state-owned banks. FOB is a dummy taking value 1 for foreignbanks. LISTED is a dummy taking value 1 for publicly traded banks. YEARS represents a vector of year (time) dummies. We estimate the empirical model in equation 3 using pooled and static panel regressions.

Carbó and Rodriguez (2007), and Maudos and Solís (2009) consider that bank interest margins is influenced by their previous values given the fact that banks have to match across periods the deposits and lending which are randomly determined as well as non-interest activities. Therefore, they argue that the determination of interest margins should also be tested using a dynamic panel method. Hence, we also estimate a dynamic panel data model employing a two-step Generalized Method of Moments/ GMM estimator ${ }^{18}$. The equations can be written as follows:

$$
\begin{aligned}
& N_{i M}=\alpha_{0}+\alpha_{1} \text { NIM }_{i, t-1}+\alpha_{2} \text { SMALL }_{i, t}+\alpha_{3} \text { PROPERTY }_{i, t}+\alpha_{4} \text { LERNER }_{i, t}+\alpha_{5} \text { OVERHEAD }_{i, t}+ \\
& \alpha_{6} C_{i R_{i, t}}+\alpha_{7} E_{Q T A} A_{i, t}+\alpha_{8} N P L_{i, t}+\alpha_{9} L D R_{i, t}+\alpha_{10} S O B_{i}+\alpha_{11} F_{O B}+\alpha_{12} \text { LISTED }_{i, t}+ \\
& Y E A R S+\varepsilon_{i, t}
\end{aligned}
$$

\footnotetext{
${ }^{18}$ We use a two-step GMM estimator, particularly the System GMM proposed by Arellano and Bover (1995) and Blundell and Bond (1998) which extends the standard GMM of Arellano and Bond (1991). The System GMM estimator uses both first-differences and levels.
} 


$$
\begin{aligned}
& \operatorname{NIM}_{i, t}=\alpha_{0}+\alpha_{1} \text { NIM }_{i, t-1}+\alpha_{2} \text { PROPERTY }_{i, t}+\alpha_{3} \text { LERNER }_{i, t}+\alpha_{4} \text { DIV }_{i, t}+\alpha_{5} \text { OVERHEAD }_{i, t}+ \\
& \alpha_{6} \mathrm{CIR}_{i, t}+\alpha_{7} \mathrm{EQTA}_{i, t}+\alpha_{8} N P L_{i, t}+\alpha_{9} L_{\mathrm{D} R_{i, t}}+\alpha_{10} \mathrm{SOB}_{i}+\alpha_{11} \mathrm{FOB}_{i}+\alpha_{12} \text { LISTED }_{i, t}+ \\
& Y E A R S+\varepsilon_{i, t}
\end{aligned}
$$

\section{Results}

\subsection{Descriptive Statistics}

Table 1 presents the descriptive statistics for the variables of our full sample and the sub-samples by ownership type (state-owned banks, foreign banks, and private-domestic banks), while table 2 reports the statistics year by year. The dependent variable (NIM) has a mean (median) of $6.61 \%$ (5.91\%). As shown in table 2, the yearly average interest margins of Indonesian banks are persistently high during the period we study. The means (medians) of the proportion of small scale loans and the proportion of property loans are $16.33 \%(7.78 \%)$ and $4.98 \%(0.77 \%)$ respectively. The mean (median) of Lerner index is $0.393(0.369)$, while the average (median) of the diversification index is $16.61 \%(11.51 \%)$. The ratio of overhead costs to total assets has an average (median) of $3.73 \%(3.61 \%)$, whereas the cost to income ratio has a mean (median) of $79.48 \%(80.25 \%)$. The average size (total assets) is 20,593.86 billion Rupiah. The smallest bank has assets of 52.65 billion Rupiah, while 370,000 billion Rupiah is the total assets of the largest bank. $11.76 \%$ (9.73\%) is the average (median) of the ratio of equity to total assets. The mean (median) of the ratio of non-performing loans to total loans is $4 \%(2.8 \%)$. The average (median) of the loans to deposits ratio in our sample is $74.18 \%(69.78 \%)$.

Insert Table 1 here

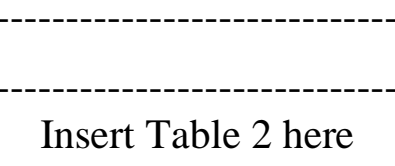

\subsection{Correlation Matrix}

Table 3 reports the correlation matrix between variables of this study. The correlations between the dependent variable (interest margin) and the explanatory variables are shown in the first column of the table. As expected, net interest margins (NIM) is found to be positively correlated with small scale loans, the Lerner index, the ratio of overhead costs to total assets, and the ratio of equity to total assets. We observe, as expected, negative 
correlations between NIM and property loans, diversification, the cost to income ratio, as well as between NIM and size. The ratio of non-performing loans to total loans and the loans to deposits ratio are found to be negatively correlated with NIM.

Insert Table 3 here

\subsection{Regressions}

We analyze the determinants of interest margins of Indonesian banks by employing pooled regression and static panel regression techniques, as well as a two-step GMM estimator. Table 4 presents the regression results of pooled regression (column 1, 2 and 3), random effect panel data (column 4, 5 and 6), and two-step GMM estimation (column 7, 8 and 9). The Wald test, the Sargan test, and the Arellano-Bond test (autocorrelation) of the GMM estimation meet the requirements. The Wald test in the random effect model is found to satisfy the requirement as well.

Insert Table 4 here

As expected, we find a positive and significant impact of small scale loans (SMALL) on interest margins (NIM) in all models. Banks with a greater proportion of small scale loans in their loan portfolio set a higher interest margin. In the pooled regression, the ratio of property loans to total loans (PROPERTY), as expected, has a negative effect on interest margins. However, the coefficient of this variable is not significant in the random effect panel data and GMM estimations. In line with Beck and Hesse (2009), the results suggest that the structure of bank loan portfolios matters in the determination of interest margins. Banks set a higher interest margin if they are more exposed to riskier loans.

As shown in all models, we confirm the findings of Maudos and de Guevara (2004), and Maudos and Solís (2009) that market power, measured by Lerner index (LERNER), is positively associated with interest margins. Banks set a higher interest margins when they face relatively inelastic demand and supply functions in the markets enabling them to exercise their monopoly power (Ho and Saunders, 1981).

Our results is consistent with the loss leader hypothesis on the cross-subsidization strategy of income diversification (Lepetit et al., 2008; Maudos and Solís, 2009), as shown by the negative coefficients of the diversification index (DIV) in all regression models. More 
diversified banks charge a lower interest rate as they are able to gain a higher income from non-interest activities because the lower rate might attract new clients to the banks. Such clients are expected to buy fee generating services from the bank. Subsequently, more diversified banks have a lower interest margin.

We find that the ratio of overhead costs to total assets (OVERHEAD) is positively and significantly associated with interest margins using all methods. These results confirm the findings of Beck and Hesse (2009) and Maudos and Solís (2009) as well as the extension of the dealership model proposed by Maudos and de Guevara (2004) which includes operating costs to represent how efficient banks are in their production process. As expected, the second proxy of efficiency which is the cost to income ratio (CIR) has a negative impact on interest margins using all methods. This result confirms the finding of Maudos and de Guevara (2004), Maudos and Solís (2009) and Lopez-Espinosa et al. (2011).

Strong evidence is also found regarding the negative effect of bank size, measured by the natural logarithm of total assets orthogonalized with equity (ORTHOLNTA) on interest margins. This negative impact confirms the hypothesis that large banks achieve economies of scale that can decrease their margins (Beck and Hesse, 2009; Fungáčová and Poghosyan, 2011). The ratio of equity to total assets (EQTA) which is a proxy of risk aversion has a positive and significant coefficient in all the regressions. In line with the dealership model (Ho and Saunders, 1981) higher managerial risk aversion will increase interest margins. This result is similar to those of previous studies such as Maudos and Solís (2009), Poghosyan (2010).

Our results show that credit risk, measured by the ratio of non-performing loans to total loans (NPL), has a negative and significant effect on interest margins in the pooled and random effect regression models which confirm the finding of Fungáčová and Poghosyan (2011). The results are also in line with the findings of Hadad et al., (2011) that in Indonesia market discipline by depositors is pronounced in the price of deposits. Depositors require a higher interest rate on deposits for riskier banks. The loans to deposits ratio (LDR) as the proxy of liquidity risk has a positive impact on bank margins using all regression methods. The results are consistent with the findings of Maudos and de Guevara (2004), LópezEspinosa et al. (2011), Chen and Liao (2011). More liquid banks (banks with lower liquidity risk) with higher opportunity cost have lower interest margins.

Regarding the influence of bank ownership, in all our models, the coefficient of the dummy for state-owned banks (SOB) exhibits a positive and significant sign. The results show that state-owned banks set a higher interest margin than other banks. There are a 
number of possible explanations for such a result. First, as they are perceived less risky by depositors because of implicit guarantee and too-big-to-fail considerations, specifically by a large number of small depositors, they can easily obtain resources under the form deposits with a lower cost than other funds. Second, as explained by Rosengard and Prasetyantoko (2011), the higher interest margins of Indonesian state-owned banks (both provincial and central) are mainly driven inefficiency considerations. Third, labor surplus in these banks may contribute to increase the operating costs which subsequently lead them to increase their margins.

The coefficient of the dummy for foreign banks (FOB) is found to be negative and significant in all models. The results are consistent with those of previous studies such as Martinez-Peria and Mody (2004) in which foreign banks are found to charge a lower interest margin than domestic banks. This evidence may result from the better hard information and technology from which foreign banks benefit which in turn enables them to perform more efficiently than domestic banks.

Finally, we find little evidence on the difference regarding interest margins between listed (LISTED) and non-listed banks in all models.

\subsection{Robustness Checks}

We conduct several robustness checks. Firstly, we follow the method of Maudos and de Guevarra (2004) by replacing the Lerner index by the Herfindahl Hirschman Index (HHI), calculated on the basis of total assets, as a measure of banking market structure. As expected, the coefficient of $\mathrm{HHI}$ is positive and significant in some models, while the results for the other variables are stable (the results are presented in table 5).

Insert Table 5 here

Secondly, we exclude the dummy for state-owned banks (SOB), the dummy for foreign banks (FOB), and the dummy for listed banks (LISTED) to enable us to test the empirical model using fixed-effect panel data techniques. For all the remaining variables, except for the Lerner index, the results are similar to those of the random effect regressions presented in column $4-6$ of table 4 although the effect of the Lerner index is slightly weaker but still significant. 


\section{Conclusion and Policy Implications}

We analyze the determinants of net interest margins in Indonesia after the 1997/1998 financial crisis. We use data of 93 commercial banks over the 2001-2009 period. We estimate the empirical model using pooled regression techniques as well as static and dynamic panel methods.

We confirm that the structure of loan portfolio matters in the determination of interest margins. In the context of Indonesian banking, small scale loans contribute to increase bank margins, whereas housing (property) loans reduce interest margins. Our results also show that Indonesian banks with a greater market power set higher interest margins. Furthermore, we also corroborate the loss leader hypothesis on cross-subsidization of lending and non-interest activities. The results also validate that higher margins are driven by higher operating costs, higher risk aversion and higher liquidity risk. Consistent with previous literature the cost to income ratio is also found to negatively affect intermediation margins. We also find that credit risk has a negative impact on bank margins. Strong evidence is found that large banks set lower interest margins.

We then turn our analysis to the role of ownership as a determinant of interest margins. Considering whether there is a difference in interest margins between state-owned (government) banks and private banks, we find that the latter have lower margins. Our findings also confirm that foreign banks are beneficial to the banking sector and the economy as a whole as they charge lower margins.

These empirical results have several noteworthy policy implications. Firstly, we show that banks with a higher market power "enjoy" higher interest margins. Therefore, promoting a more healthy banking competition should be pursued by regulators to specifically improve transparency and disclosure on banking products. Secondly, the regulation on the transparency of the prime lending rate has been released by the Bank Indonesia in March 2011 but only for corporate, retail, housing and consumption loans. Extending the regulation on prime lending rates to include loans to MSMEs should be strongly recommended. Thirdly, the positive impact of small scale loans on interest margins may come from the fact that loans to micro, small and medium enterprises require a higher risk premium. Imposing on banks that they charge a lower rate on these loans may not be a proper answer as these loans are costly and riskier. Regulators should therefore direct banks to appropriately estimate risk 
premia on loans to MSMEs, for instance by using credit scoring systems. Lastly, Regulators need to bring banks to perform more efficiently.

\section{References}

Agung, J., Kusmiarso, B., Pramono, B., Hutapea, E.G., Prasmuko, A., Prastowo, N.J., 2001. Credit crunch in Indonesia in the aftermath of the crisis: Facts, causes and policy implications. Policy paper, Directorate of Economic Research and Monetary Policy, Bank Indonesia.

Angbazo, L., 1997. Commercial bank net interest margins, default risk, interest rate risk and off-balance sheet banking. Journal of Banking \& Finance 21, 55-87.

Allen, L., 1988. The determinants of bank interest margins: a note. Journal of Financial and Quantitative Analysis 23, 231-235.

Arellano, M., Bond, S., 1991. Some tests of specification for panel data: Monte Carlo evidence and an application to employment equations. Reviews of Economic Studies 58, 277-297.

Arellano, M., Bover, O., 1995. Another look at the instrumental variable estimation of errorcomponent models. Journal of Econometrics 68, 29-51.

Barry, T.A., Lepetit, L., Tarazi, A., 2011. Ownership structure and risk in publicly held and privately owned banks. Journal of Banking \& Finance 35, 1327-1340.

Beck, T., Hesse, H., 2009. Why are interest spreads so high in Uganda? Journal of Development Economics 88, 192-204.

Behr, P., Entzian, A., Güttler, A., 2011. How do lending relationships affect access to credit and loan conditions in microlending? Journal of Banking \& Finance 35, 2169-2178.

Blundell, R. and S. Bond., 1998. Initial conditions and moment restrictions in dynamic panel data models. Journal of Econometrics 87, 115-143.

Carbó Valverde, S., Rodriguez Fernandez, F., 2007. The determinants of bank margins in European banking. Journal of Banking \& Finance 31, 2043-2063.

Chen, S-H., Liao, C-C., 2011. Are foreign banks more profitable than domestic banks? Home- and host-country effects of banking market structure, governance, and supervision. Journal of Banking \& Finance 35, 819-839.

Claessens, S., Kunt, D., Huizinga, H., 2001. How does foreign entry affect domestic banking markets? Journal of Banking \& Finance 25, 891-911.

Claeys, S., Vennet, R.V., 2008. Determinants of bank interest margins in Central and Eastern Europe: A comparison with the West. Economic Systems 32, 197-216 
De la Torre, A., Martínez Pería, M.S., Schmukler, S.L., 2010. Bank involvement with SMEs: Beyond relationship lending. Journal of Banking \& Finance 34, 2280-2293.

Demirgüç-Kunt, A., Huizinga, H., 1998. Determinants of commercial bank interest margins and profitability: some international evidence. World Bank Policy Research Working Paper 1900.

Ding, W., Domac, I., Ferri., G., 1998. Is there a credit crunch in East Asia? World Bank Policy Research Working Paper No. 1959.

Drakos, K., 2003. Assessing the success of reform in transition banking 10 years later: an interest margins analysis. Journal of Policy Modeling 25, 309-317.

Elsas, R., Hackethal, A., Holzhäuser, M., 2010. The anatomy of bank diversification. Journal of Banking \& Finance 34, 1274-1287.

Fungáčová, Z., Poghosyan, T., 2011. Determinants of bank interest margins in Russia: Does bank ownership matter? Economic Systems 35, 481-495.

Hadad, M.D., Agusman, A., Monroe, G.S., Gasbarro, D., Zumwalt, J.K., 2011. Market discipline, financial crisis and regulatory changes: Evidence from Indonesian banks. Journal of Banking \& Finance 35, 1552-1562.

Hamada, M., 2003. Transformation of the financial sector in Indonesia. IDE Research Paper No. 6.

Hawtrey, K., Liang, H., 2008. Bank interest margins in OECD countries. North American Journal of Economics and Finance 19, 249-260.

Hayashi, M., 2002. The role of subcontracting in SME development in Indonesia: Microlevel evidence from the metalworking and machinery industry. Journal of Asian Economics 13, 1-26.

Hill, H., 2001. Small and medium enterprises in Indonesia: Old policy challenges for a new administration. Asian Survey 41, 248-270.

Ho, T., Saunders, A., 1981. The determinants of bank interest margins: theory and empirical evidence. Journal of Financial and Quantitative Analysis 16, 581-600.

Hoek-Smit, M.C., 2005. The housing finance sector in Indonesia. Working Paper, The Housing Finance Business Group, World Bank.

Koetter, M., Kolari, J.W., Spierdijk, J., 2012. Enjoying the quiet life under deregulation? Evidence from adjusted lerner indices for U.S. banks. Review of Economics and Statistics 94, 462-480.

Lin, J-R., Chung, H., Hsieh, M-H., Wu, S., 2012. The determinants of interest margins and their effect on bank diversification: Evidence from Asian banks. Journal of Financial Stability 8, 96- 106. 
Lepetit, L., Nys, E., Rous, P., Tarazi, A., 2008. The expansion of services in European banking: implications for loan pricing and interest margins. Journal of Banking \& Finance 32, 2325-2335.

López-Espinosa, G., Moreno, A., de Gracia, F.P., 2011. Banks' net interest margin in the 2000s: A macro-accounting international perspective. Journal of International Money and Finance 30, 1214-1233.

Martinez Peria, M., Mody, A., 2004. How foreign participation and market concentration impact bank spreads: evidence from Latin America. Journal of Money Credit and Banking 36, 511-537.

Maudos, J., de Guevara, J.F., 2004. Factors explaining the interest margin in the banking sectors of the European Union. Journal of Banking \& Finance 28, 2259-2281.

Maudos, J., Solís, L., 2009. The determinants of net interest income in the Mexican banking system: an integrated model. Journal of Banking \& Finance 33, 1920-1931.

Micco, A., Panizza, U., Yanez, M., 2007. Bank ownership and performance. Does politics matter? Journal of Banking \& Finance 31, 219-241.

Mondscean, T.S, Opiela, T.P., 1999. Bank time deposit rates and market discipline in Poland: The impact of state ownership and deposit insurance reform. Journal of Financial Services Research 15, 179-196.

Najib M., Kiminami, A. Yagi, H., 2011. Competitiveness of Indonesian small and medium food processing industry: Does the location matter? International Journal of Business and Management 6, 57-67.

Poghosyan, T., 2010. Re-examining the impact of foreign bank participation on interest margins in emerging markets. Emerging Markets Review 11, 390-403.

Rosengard, J.K., Prasetyantoko, A., 2011. If the banks are doing so well, why can't I get a loan? Regulatory constraints to financial inclusion in Indonesia. Asian Economic Policy Review 6, 273-296.

Saunders, A., Schumacher, L., 2000. The determinants of bank interest rate margins: an international study. Journal of International Money and Finance 19, 813-832.

Wattanapruttipaisan, T., 2003. Four proposals for improved financing of SME development in ASEAN. Asian Development Review 20, 66-104.

Weill, L., 2011. Do Islamic banks have greater market power? Comparative Economic Studies 53, 291-306. 
Table 1: Descriptive Statistics - based on ownership type

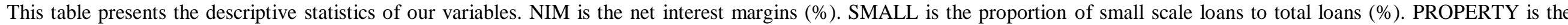

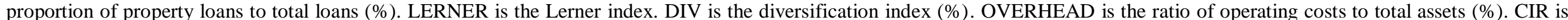

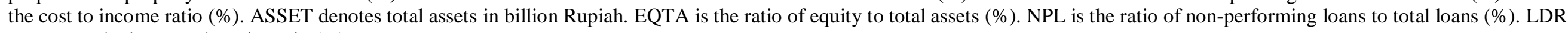
represents the loans to deposits ratio (\%).

\begin{tabular}{|c|c|c|c|c|c|c|c|c|c|c|c|c|c|}
\hline Sample & Banks & Statistics & NIM & SMALL & PROPERTY & LERNER & DIV & OVERHEAD & CIR & $\begin{array}{c}\text { ASSETS } \\
\text { (billion } \\
\text { Rupiah) }\end{array}$ & EQTA & NPL & LDR \\
\hline \multirow[t]{6}{*}{ Full Sample } & \multirow[t]{6}{*}{617} & Mean & 6.693 & 16.697 & 5.037 & 0.391 & 16.068 & 3.700 & 79.205 & 21003.25 & 11.760 & 3.999 & 74.181 \\
\hline & & Median & 5.980 & 8.030 & 0.786 & 0.366 & 11.301 & 3.616 & 80.144 & 4070.27 & 9.729 & 2.800 & 69.781 \\
\hline & & Maximum & 16.640 & 100.000 & 53.610 & 2.208 & 57.349 & 16.729 & 219.940 & 370000 & 51.069 & 44.000 & 313.446 \\
\hline & & Minimum & -0.650 & 0.000 & 0.000 & -7.930 & 0.864 & 0.195 & 21.850 & 52.65 & 0.466 & 0.010 & 5.104 \\
\hline & & Std. Dev. & 3.046 & 22.039 & 8.722 & 0.507 & 12.609 & 1.668 & 18.846 & 49010.14 & 7.348 & 4.519 & 38.775 \\
\hline & & Skewness & 0.828 & 1.971 & 2.771 & -7.020 & 1.324 & 1.319 & 1.710 & 4.08189 & 1.940 & 3.443 & 2.133 \\
\hline \multirow{6}{*}{$\begin{array}{l}\text { State-owned } \\
\text { Banks }\end{array}$} & \multirow[t]{6}{*}{207} & Mean & 9.109 & 31.901 & 4.568 & 0.535 & 10.299 & 4.265 & 76.575 & 32029.3 & 9.077 & 3.165 & 60.772 \\
\hline & & Median & 9.230 & 21.370 & 0.328 & 0.547 & 8.392 & 4.403 & 76.570 & 4566.6 & 8.656 & 2.010 & 56.458 \\
\hline & & Maximum & 16.640 & 100.000 & 53.610 & 0.995 & 31.043 & 7.589 & 108.290 & 370000 & 19.274 & 26.660 & 129.593 \\
\hline & & Minimum & 0.900 & 0.000 & 0.000 & -0.075 & 2.573 & 0.958 & 38.920 & 208.62 & 3.133 & 0.090 & 10.037 \\
\hline & & Std. Dev. & 3.097 & 27.435 & 10.700 & 0.260 & 5.973 & 1.456 & 9.561 & 71330.99 & 3.137 & 3.433 & 25.996 \\
\hline & & Skewness & 0.095 & 1.091 & 3.302 & -0.140 & 1.347 & -0.091 & -0.370 & 2.836817 & 0.833 & 3.189 & 0.341 \\
\hline \multirow[t]{6}{*}{ Foreign Banks } & \multirow[t]{6}{*}{127} & Mean & 4.741 & 0.302 & 1.129 & 0.484 & 33.237 & 2.711 & 65.700 & 10907.23 & 15.216 & 5.948 & 111.844 \\
\hline & & Median & 4.390 & 0.000 & 0.000 & 0.507 & 35.386 & 2.509 & 63.620 & 5509.92 & 14.520 & 4.090 & 98.983 \\
\hline & & Maximum & 10.000 & 13.000 & 19.765 & 1.991 & 57.349 & 8.537 & 219.000 & 52329.46 & 40.872 & 44.000 & 313.446 \\
\hline & & Minimum & 1.470 & 0.000 & 0.000 & -0.997 & 6.865 & 0.195 & 21.850 & 410.01 & 0.466 & 0.100 & 22.466 \\
\hline & & Std. Dev. & 1.653 & 1.462 & 3.046 & 0.468 & 13.682 & 1.507 & 24.910 & 11548.69 & 9.013 & 6.132 & 57.073 \\
\hline & & Skewness & 0.824 & 6.582 & 4.058 & -0.435 & -0.250 & 0.862 & 2.318 & 1.546831 & 0.211 & 2.766 & 1.365 \\
\hline \multicolumn{14}{|l|}{ Private } \\
\hline Domestic & \multirow[t]{6}{*}{283} & Mean & 5.802 & 12.933 & 7.134 & 0.243 & 12.583 & 3.730 & 87.190 & 17468.99 & 12.170 & 3.735 & 67.087 \\
\hline \multirow[t]{5}{*}{ Banks } & & Median & 5.570 & 7.310 & 4.869 & 0.187 & 10.124 & 3.529 & 86.930 & 2403.2 & 9.866 & 2.750 & 68.753 \\
\hline & & Maximum & 15.100 & 81.130 & 41.081 & 2.208 & 43.298 & 16.729 & 219.940 & 281000 & 51.069 & 29.020 & 152.650 \\
\hline & & Minimum & -0.650 & 0.010 & 0.000 & -7.930 & 0.864 & 1.012 & 34.450 & 52.65 & 1.301 & 0.010 & 5.104 \\
\hline & & Std. Dev. & 2.291 & 14.328 & 8.181 & 0.611 & 8.259 & 1.683 & 16.752 & 36370.19 & 7.976 & 4.113 & 22.667 \\
\hline & & Skewness & 0.957 & 2.167 & 1.422 & -8.159 & 1.118 & 2.662 & 3.180 & 3.953469 & 2.350 & 3.597 & -0.128 \\
\hline
\end{tabular}




\section{Table 2: Descriptive statistics year by year}

This table presents the descriptive statistics of our variables. NIM is the net interest margins (\%). SMALL is the proportion of small scale loans to total loans (\%). PROPERTY is the proportion of property loans to total loans (\%). LERNER is the Lerner index. DIV is the diversification index (\%). OVERHEAD is the ratio of operating costs to total assets (\%). CIR is the cost to income ratio (\%). ASSET denotes total assets in billion Rupiah. EQTA is the ratio of equity to total assets (\%). NPL is the ratio of non-performing loans to total loans (\%). LDR represents the loans to deposits ratio (\%).

\begin{tabular}{|c|c|c|c|c|c|c|c|c|c|c|c|c|c|}
\hline Year & Banks & Statistics & NIM & SMALL & PROPERTY & LERNER & DIV & OVERHEAD & CIR & $\begin{array}{c}\text { ASSETS } \\
\text { (billion } \\
\text { Rupiah) }\end{array}$ & EQTA & NPL & LDR \\
\hline \multirow[t]{2}{*}{2001} & 59 & Mean & 6.617 & 28.156 & 2.308 & 0.322 & 12.699 & 3.178 & 82.269 & 14721.88 & 9.432 & 6.749 & 54.147 \\
\hline & & Std. Dev. & 3.500 & 31.972 & 4.669 & 1.160 & 11.133 & 1.365 & 26.150 & 40384.47 & 7.061 & 8.110 & 31.037 \\
\hline \multirow[t]{2}{*}{2002} & 62 & Mean & 6.626 & 21.776 & 2.993 & 0.488 & 14.619 & 3.675 & 82.543 & 14935.41 & 11.186 & 5.475 & 64.823 \\
\hline & & Std. Dev. & 3.461 & 25.206 & 5.846 & 0.375 & 12.450 & 1.700 & 26.432 & 38919.5 & 7.076 & 6.136 & 38.392 \\
\hline \multirow[t]{2}{*}{2003} & 67 & Mean & 6.600 & 21.824 & 3.823 & 0.394 & 16.328 & 3.633 & 78.626 & 15064.21 & 11.647 & 4.375 & 67.826 \\
\hline & & Std. Dev. & 3.127 & 25.373 & 7.322 & 0.428 & 14.029 & 1.737 & 19.116 & 38450.43 & 6.892 & 4.720 & 37.177 \\
\hline \multirow[t]{2}{*}{2004} & 70 & Mean & 7.040 & 17.664 & 4.954 & 0.476 & 19.945 & 3.826 & 75.402 & 16146.19 & 11.253 & 4.095 & 73.471 \\
\hline & & Std. Dev. & 3.541 & 20.592 & 8.916 & 0.353 & 15.554 & 2.247 & 22.221 & 38578.98 & 5.738 & 4.181 & 40.784 \\
\hline \multirow[t]{2}{*}{2005} & 76 & Mean & 6.931 & 14.949 & 4.983 & 0.392 & 15.929 & 3.889 & 78.967 & 17700.96 & 11.485 & 3.977 & 77.036 \\
\hline & & Std. Dev. & 3.217 & 19.566 & 8.979 & 0.445 & 11.980 & 1.543 & 16.369 & 39669.33 & 7.210 & 3.782 & 39.823 \\
\hline \multirow[t]{2}{*}{2006} & 73 & Mean & 6.801 & 13.384 & 5.993 & 0.386 & 14.341 & 3.805 & 79.703 & 20858.44 & 11.187 & 3.577 & 72.277 \\
\hline & & Std. Dev. & 3.017 & 16.527 & 9.762 & 0.346 & 10.974 & 1.963 & 15.301 & 44155.58 & 6.173 & 2.940 & 41.036 \\
\hline \multirow[t]{2}{*}{2007} & 75 & Mean & 6.299 & 12.127 & 5.289 & 0.381 & 16.757 & 3.547 & 78.751 & 23850.96 & 13.842 & 2.794 & 81.201 \\
\hline & & Std. Dev. & 2.545 & 17.074 & 9.066 & 0.359 & 11.710 & 1.425 & 14.082 & 52646.65 & 10.008 & 2.169 & 42.054 \\
\hline \multirow[t]{2}{*}{2008} & 67 & Mean & 6.792 & 12.143 & 7.118 & 0.344 & 16.713 & 3.845 & 78.874 & 30890.52 & 12.369 & 2.565 & 86.478 \\
\hline & & Std. Dev. & 2.683 & 18.442 & 10.231 & 0.356 & 12.706 & 1.412 & 13.608 & 62775.35 & 7.376 & 2.215 & 29.757 \\
\hline \multirow[t]{2}{*}{2009} & 68 & Mean & 6.510 & 11.112 & 7.257 & 0.330 & 16.680 & 3.813 & 78.550 & 33800.89 & 12.959 & 3.018 & 86.085 \\
\hline & & Std. Dev. & 2.287 & 17.161 & 10.289 & 0.339 & 11.721 & 1.329 & 13.449 & 71343.04 & 7.146 & 2.756 & 36.378 \\
\hline
\end{tabular}


Table 3: Correlation Matrix

This table presents the pairwise correlation between the variables used in this study. NIM is the net interest margins (\%). SMALL is the proportion of small scale loans to total loans (\%). PROPERTY is the proportion of property loans to total loans (\%). LERNER is the Lerner index. DIV is the diversification index (\%). OVERHEAD is the ratio of operating costs to total assets (\%). CIR is the cost to income ratio (\%). ORTHOLNTA denotes the natural logarithm of total assets orthogonalized with equity. EQTA is the ratio of equity to total assets (\%). NPL is the ratio of non-performing loans to total loans (\%). LDR represents the loans to deposits ratio (\%).

\begin{tabular}{|c|c|c|c|c|c|c|c|c|c|c|c|}
\hline & NIM & SMALL & PROPERTY & LERNER & DIV & OVERHEAD & CIR & ORTHOLNTA & EQTA & NPL & LDR \\
\hline NIM & 1 & & & & & & & & & & \\
\hline SMALL & 0.384 & 1 & & & & & & & & & \\
\hline PROPERTY & -0.165 & -0.025 & 1 & & & & & & & & \\
\hline LERNER & 0.192 & 0.069 & -0.082 & 1 & & & & & & & \\
\hline DIV & -0.400 & -0.378 & -0.059 & 0.122 & 1 & & & & & & \\
\hline OVERHEAD & 0.339 & 0.178 & -0.053 & -0.032 & -0.081 & 1 & & & & & \\
\hline CIR & -0.158 & 0.108 & 0.055 & -0.207 & -0.116 & 0.176 & 1 & & & & \\
\hline ORTHOLNTA & -0.182 & -0.276 & 0.200 & 0.137 & 0.359 & -0.331 & -0.318 & 1 & & & \\
\hline EQTA & 0.124 & -0.081 & -0.086 & -0.014 & -0.085 & 0.005 & -0.196 & 0.000 & 1 & & \\
\hline NPL & -0.251 & -0.082 & -0.044 & 0.044 & 0.274 & -0.023 & 0.226 & -0.003 & 0.007 & 1 & \\
\hline LDR & -0.035 & -0.222 & -0.071 & -0.034 & 0.138 & -0.011 & -0.057 & 0.100 & 0.302 & 0.068 & 1 \\
\hline
\end{tabular}




\section{Table 4: Regressions results}

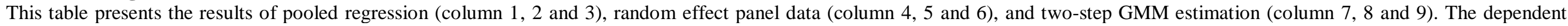

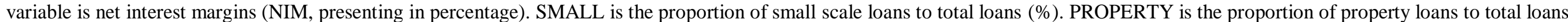

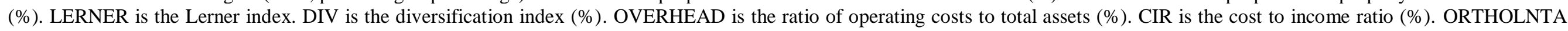

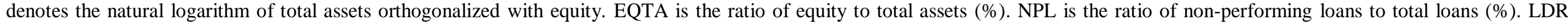

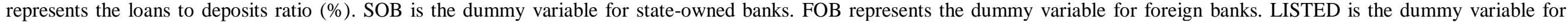
publicly traded banks. The values in parentheses are standard errors. $*, * *$ and $* * *$ indicate significance at the $10 \%, 5 \%$, and $1 \%$ levels, respectively.

\begin{tabular}{|c|c|c|c|c|c|c|c|c|c|}
\hline & & & & ependent V & le: Net Inter & Margin (NIN & & & \\
\hline & & Pooled & & & andom Effe & & & GMM & \\
\hline & 1 & 2 & 3 & 4 & 5 & 6 & 7 & 8 & 9 \\
\hline NIM (t-1) & & & & & & & $\begin{array}{c}0.378 * * * \\
(0.030)\end{array}$ & $\begin{array}{c}0.419 * * * \\
(0.042)\end{array}$ & $\begin{array}{c}0.387 * * * \\
(0.030)\end{array}$ \\
\hline SMALL & $\begin{array}{c}0.010 * * \\
(0.004)\end{array}$ & $\begin{array}{c}0.008^{*} \\
(0.005)\end{array}$ & & $\begin{array}{c}0.013 * * * \\
(0.004)\end{array}$ & $\begin{array}{c}0.010 * * \\
(0.005)\end{array}$ & & $\begin{array}{c}0.009 * * \\
(0.004)\end{array}$ & $\begin{array}{c}0.007 \\
(0.005)\end{array}$ & \\
\hline PROPERTY & $\begin{array}{c}-0.038 * * * \\
(0.009)\end{array}$ & $\begin{array}{c}-0.041 * * * \\
(0.011)\end{array}$ & $\begin{array}{c}-0.035 * * * \\
(0.009)\end{array}$ & $\begin{array}{l}-0.014 \\
(0.012)\end{array}$ & $\begin{array}{c}0.003 \\
(0.014)\end{array}$ & $\begin{array}{l}-0.013 \\
(0.012)\end{array}$ & $\begin{array}{l}-0.002 \\
(0.014)\end{array}$ & $\begin{array}{c}0.013 \\
(0.015)\end{array}$ & $\begin{array}{l}-0.001 \\
(0.013)\end{array}$ \\
\hline LERNER & $\begin{array}{c}0.555^{* * *} \\
(0.149)\end{array}$ & $\begin{array}{c}0.858 * * * \\
(0.182)\end{array}$ & $\begin{array}{c}0.611 * * * \\
(0.146)\end{array}$ & $\begin{array}{c}0.284 * * \\
(0.124)\end{array}$ & $\begin{array}{c}0.260 * * \\
(0.131)\end{array}$ & $\begin{array}{c}0.298 * * \\
(0.123)\end{array}$ & $\begin{array}{c}0.401 * * \\
(0.168)\end{array}$ & $\begin{array}{c}0.549 * * * \\
(0.202)\end{array}$ & $\begin{array}{c}0.445 * * \\
(0.174)\end{array}$ \\
\hline DIV & & & $\begin{array}{c}-0.050 * * * \\
(0.009)\end{array}$ & & & $\begin{array}{c}-0.047 * * * \\
(0.010)\end{array}$ & & & $\begin{array}{c}-0.017 * * \\
(0.008)\end{array}$ \\
\hline OVERHEAD & $\begin{array}{c}0.839 * * * \\
(0.048)\end{array}$ & & $\begin{array}{c}0.861 * * * \\
(0.047)\end{array}$ & $\begin{array}{c}0.554 * * * \\
(0.051)\end{array}$ & & $\begin{array}{c}0.580 * * * \\
(0.050)\end{array}$ & $\begin{array}{c}0.379 * * * \\
(0.070)\end{array}$ & & $\begin{array}{c}0.378 * * * \\
(0.072)\end{array}$ \\
\hline CIR & $\begin{array}{c}-0.049 * * * \\
(0.005)\end{array}$ & & $\begin{array}{c}-0.054 * * * \\
(0.005)\end{array}$ & $\begin{array}{c}-0.035 * * * \\
(0.005)\end{array}$ & & $\begin{array}{c}-0.038 * * * \\
(0.005)\end{array}$ & $\begin{array}{c}-0.026^{* * *} * \\
(0.004)\end{array}$ & & $\begin{array}{c}-0.027 * * * \\
(0.004)\end{array}$ \\
\hline ORTHOLNTA & & $\begin{array}{c}-0.268 * * * \\
(0.075)\end{array}$ & & & $\begin{array}{c}-0.485 * * * \\
(0.120)\end{array}$ & & & $\begin{array}{c}-0.412 * * \\
(0.204)\end{array}$ & \\
\hline EQTA & $\begin{array}{c}0.059 * * * \\
(0.012)\end{array}$ & $\begin{array}{c}0.095 * * * \\
(0.013)\end{array}$ & $\begin{array}{c}0.050 * * * \\
(0.011)\end{array}$ & $\begin{array}{c}0.069 * * * \\
(0.013)\end{array}$ & $\begin{array}{c}0.112 * * * \\
(0.015)\end{array}$ & $\begin{array}{c}0.068 * * * \\
(0.013)\end{array}$ & $\begin{array}{c}0.060 * * * \\
(0.009)\end{array}$ & $\begin{array}{c}0.090 * * * \\
(0.014)\end{array}$ & $\begin{array}{c}0.062 * * * \\
(0.009)\end{array}$ \\
\hline NPL & $\begin{array}{c}-0.053 * * * \\
(0.019)\end{array}$ & $\begin{array}{c}-0.113^{* * *} \\
(0.021)\end{array}$ & $\begin{array}{l}-0.030 \\
(0.019)\end{array}$ & $\begin{array}{c}-0.042 * * \\
(0.017)\end{array}$ & $\begin{array}{c}-0.078 * * * \\
(0.016)\end{array}$ & $\begin{array}{l}-0.027 \\
(0.017)\end{array}$ & $\begin{array}{c}-0.027 * * \\
(0.012)\end{array}$ & $\begin{array}{c}-0.059 * * * \\
(0.018)\end{array}$ & $\begin{array}{l}-0.021 \\
(0.013)\end{array}$ \\
\hline LDR & $\begin{array}{l}0.004^{*} \\
(0.002)\end{array}$ & $\begin{array}{c}0.006 * * \\
(0.003)\end{array}$ & $\begin{array}{c}0.002 \\
(0.002)\end{array}$ & $\begin{array}{c}0.005 * * \\
(0.002)\end{array}$ & $\begin{array}{c}0.006^{* *} \\
(0.003)\end{array}$ & $\begin{array}{c}0.004^{*} \\
(0.002)\end{array}$ & $\begin{array}{c}0.009 * * * \\
(0.002)\end{array}$ & $\begin{array}{c}0.011 * * * \\
(0.003)\end{array}$ & $\begin{array}{c}0.008 * * * \\
(0.002)\end{array}$ \\
\hline SOB & $\begin{array}{c}2.004 * * * \\
(0.205)\end{array}$ & $\begin{array}{c}3.167 * * * \\
(0.259)\end{array}$ & $\begin{array}{c}2.065^{* * *} \\
(0.191)\end{array}$ & $\begin{array}{c}2.631 * * * \\
(0.361)\end{array}$ & $\begin{array}{c}3.865 * * * \\
(0.473)\end{array}$ & $\begin{array}{c}2.754 * * * \\
(0.335)\end{array}$ & $\begin{array}{c}0.883 * * * \\
(0.309)\end{array}$ & $\begin{array}{c}1.677 * * * \\
(0.342)\end{array}$ & $\begin{array}{l}0.999 * * * \\
(0.294) \\
26\end{array}$ \\
\hline
\end{tabular}


Table 4. (Continued)

\begin{tabular}{|c|c|c|c|c|c|c|c|c|c|}
\hline & 1 & 2 & 3 & 4 & 5 & 6 & 7 & 8 & 9 \\
\hline \multirow[t]{2}{*}{ FOB } & $-1.799 * * *$ & $-1.547 * * *$ & $-0.808 * *$ & $-1.596^{* * *}$ & $-0.901 *$ & $-0.762 *$ & $-1.517 * * *$ & -0.200 & $-1.112 * *$ \\
\hline & $(0.269)$ & $(0.334)$ & $(0.323)$ & $(0.416)$ & $(0.334)$ & $(0.443)$ & $(0.486)$ & $(0.670)$ & $(0.529)$ \\
\hline \multirow[t]{2}{*}{ LISTED } & -0.178 & -0.058 & 0.086 & -0.038 & 0.361 & 0.088 & $-0.436 * *$ & 0.008 & -0.341 \\
\hline & $(0.207)$ & $(0.306)$ & $(0.209)$ & $(0.284)$ & $(0.344)$ & $(0.279)$ & $(0.215)$ & $(0.258)$ & $(0.218)$ \\
\hline Year dummies & Included & Included & Included & Included & Included & Included & Included & Included & Included \\
\hline Constant & Included & Included & Included & $\begin{array}{c}\text { Included } \\
\text { Panel }\end{array}$ & $\begin{array}{c}\text { Included } \\
\text { Panel }\end{array}$ & $\begin{array}{c}\text { Included } \\
\text { Panel }\end{array}$ & Included & Included & Included \\
\hline Method & Pooled & Pooled & Pooled & $\begin{array}{c}\text { (Random } \\
\text { effect/GLS) }\end{array}$ & $\begin{array}{c}\text { (Random } \\
\text { effect/GLS) }\end{array}$ & $\begin{array}{c}\text { (Random } \\
\text { effect/GLS) }\end{array}$ & GMM & GMM & GMM \\
\hline Observations & 617 & 617 & 617 & 617 & 617 & 617 & 554 & 554 & 554 \\
\hline Overall R-squared & 0.678 & 0.510 & 0.692 & 0.647 & 0.478 & 0.663 & & & \\
\hline R-Squared between & & & & 0.728 & 0.560 & 0.752 & & & \\
\hline R-Squared within & & & & 0.271 & 0.171 & 0.281 & & & \\
\hline Wald Test & & & & $\begin{array}{l}\operatorname{chi} 2(19)= \\
462.59 \\
(0.000)^{* * *}\end{array}$ & $\begin{array}{l}\operatorname{chi} 2(18)= \\
227.40 \\
(0.000)^{* * *}\end{array}$ & $\begin{array}{l}\operatorname{chi} 2(19)= \\
513.87 \\
(0.000) * * *\end{array}$ & $\begin{array}{l}\operatorname{chi} 2(19)= \\
881.34 \\
(0.000) * * *\end{array}$ & $\begin{array}{l}\operatorname{chi} 2(18)= \\
842.04 \\
(0.000)^{* * *}\end{array}$ & $\begin{array}{l}\operatorname{chi} 2(19)= \\
953.44 \\
(0.000)^{* * *}\end{array}$ \\
\hline Sargan Test & & & & & & & $\begin{array}{l}\operatorname{chi} 2(32)= \\
38.45(0.201)\end{array}$ & $\begin{array}{l}\operatorname{chi} 2(32)= \\
38.45(0.201)\end{array}$ & $\begin{array}{l}\operatorname{chi} 2(32)= \\
39.08(0.181)\end{array}$ \\
\hline $\begin{array}{l}\text { Arellano-Bond test } \\
\text { for } A R(1)\end{array}$ & & & & & & & $\begin{array}{l}\mathrm{N}(0,1)= \\
-3.341 \\
(0.001) * * *\end{array}$ & $\begin{array}{l}\mathrm{N}(0,1)= \\
-3.495 \\
(0.000) * * *\end{array}$ & $\begin{array}{l}\mathrm{N}(0,1)= \\
-3.376 \\
(0.001)^{* * *}\end{array}$ \\
\hline $\begin{array}{l}\text { Arellano-Bond test } \\
\text { for } \operatorname{AR}(2)\end{array}$ & & & & & & & $\begin{array}{l}\mathrm{N}(0,1)= \\
-0.029 \\
(0.977)\end{array}$ & $\begin{array}{l}\mathrm{N}(0,1)= \\
-0.902 \\
(0.367)\end{array}$ & $\begin{array}{l}\mathrm{N}(0,1)= \\
-0.030 \\
(0.976)\end{array}$ \\
\hline
\end{tabular}




\section{Table 5: Robustness Check - alternative measure of market structure}

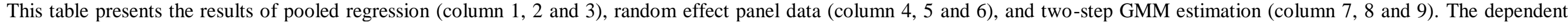

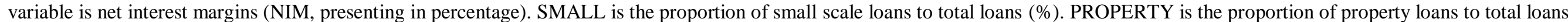

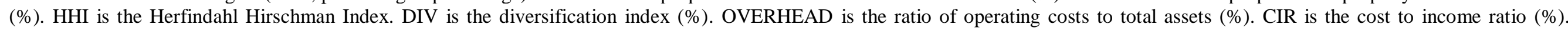

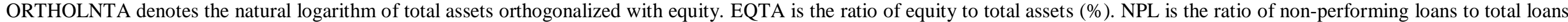

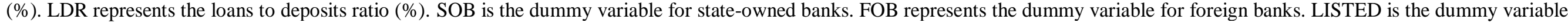
for publicly traded banks. The values in parentheses are standard errors. $*, * *$ and $* * *$ indicate significance at the $10 \%, 5 \%$, and $1 \%$ levels, respectively.

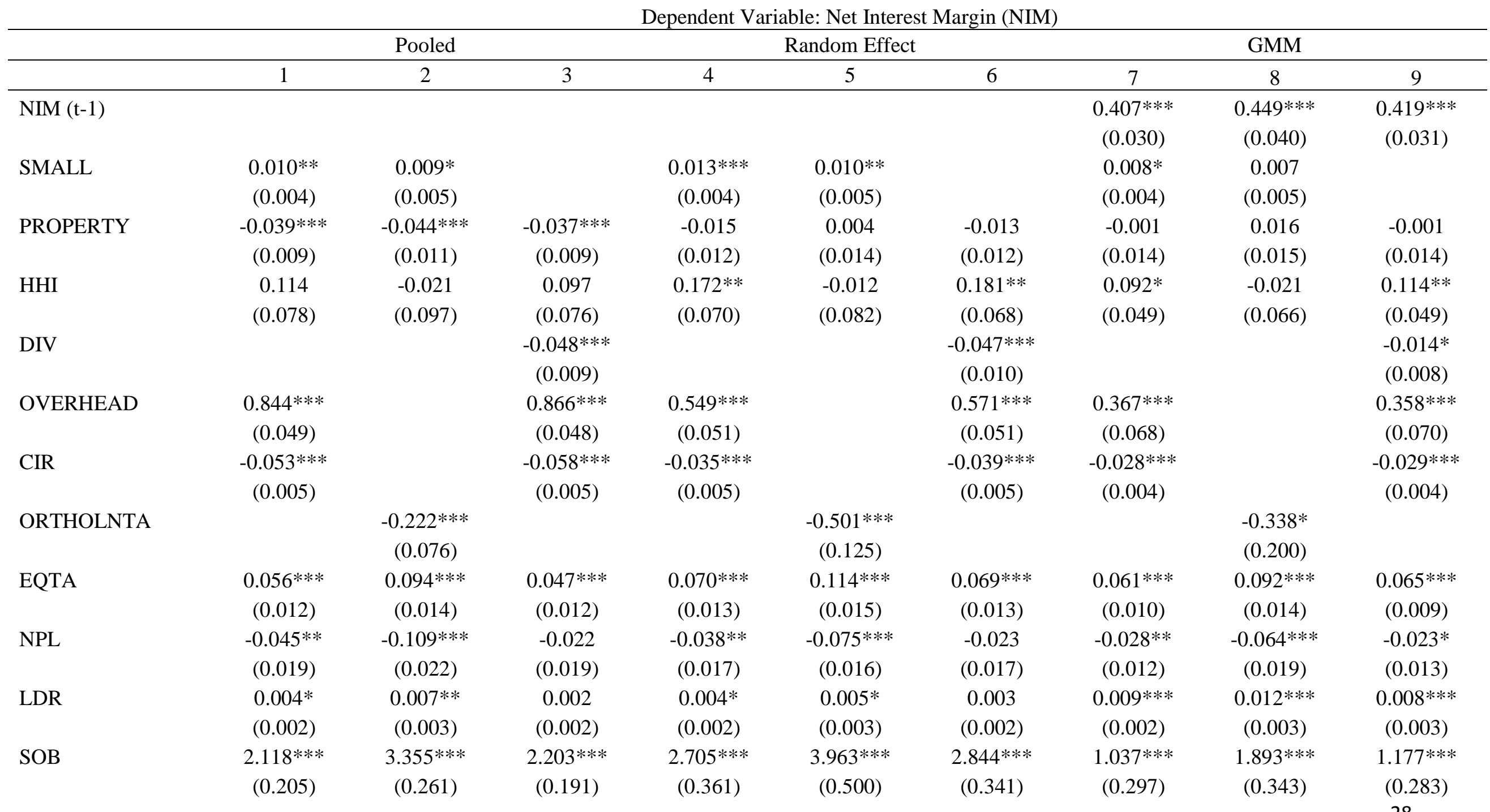


Table 5. (Continued)

\begin{tabular}{|c|c|c|c|c|c|c|c|c|c|}
\hline & 1 & 2 & 3 & 4 & 5 & 6 & 7 & 8 & 9 \\
\hline \multirow[t]{2}{*}{ FOB } & $-1.738 * * *$ & $-1.435^{* * *}$ & $-0.791 * *$ & $-1.557 * * *$ & -0.817 & $-0.723 *$ & $-1.327 * * *$ & -0.193 & $-1.028 *$ \\
\hline & $(0.271)$ & $(0.339)$ & $(0.328)$ & $(0.418)$ & $(0.558)$ & $(0.450)$ & $(0.500)$ & $(0.631)$ & $(0.542)$ \\
\hline \multirow[t]{2}{*}{ LISTED } & -0.154 & -0.119 & 0.095 & -0.040 & 0.373 & 0.089 & -0.336 & 0.089 & -0.256 \\
\hline & $(0.210)$ & $(0.311)$ & $(0.212)$ & $(0.286)$ & $(0.346)$ & $(0.282)$ & $(0.209)$ & $(0.245)$ & $(0.213)$ \\
\hline Year dummies & Included & Included & Included & Included & Included & Included & Included & Included & Included \\
\hline Constant & Included & Included & Included & $\begin{array}{l}\text { Included } \\
\text { Panel }\end{array}$ & $\begin{array}{c}\text { Included } \\
\text { Panel }\end{array}$ & $\begin{array}{c}\text { Included } \\
\text { Panel }\end{array}$ & Included & Included & Included \\
\hline Method & Pooled & Pooled & Pooled & $\begin{array}{c}\text { (Random } \\
\text { effect/GLS) }\end{array}$ & $\begin{array}{c}\text { (Random } \\
\text { effect/GLS) }\end{array}$ & $\begin{array}{c}\text { (Random } \\
\text { effect/GLS) }\end{array}$ & GMM & GMM & GMM \\
\hline Observations & 617 & 617 & 617 & 617 & 617 & 617 & 554 & 554 & 554 \\
\hline Overall R-squared & 0.670 & 0.491 & 0.683 & 0.639 & 0.466 & 0.663 & & & \\
\hline R-Squared between & & & & 0.73 & 0.546 & 0.752 & & & \\
\hline R-Squared within & & & & 0.266 & 0.170 & 0.281 & & & \\
\hline Wald Test & & & & $\begin{array}{l}\operatorname{chi} 2(18)= \\
452.75 \\
(0.000) * * *\end{array}$ & $\begin{array}{l}\operatorname{chi} 2(17)= \\
210.67 \\
(0.000) * * *\end{array}$ & $\begin{array}{l}\operatorname{chi} 2(18)= \\
493.07 \\
(0.000)^{* * *}\end{array}$ & $\begin{array}{l}\operatorname{chi} 2(18)= \\
897.39 \\
(0.000) * * *\end{array}$ & $\begin{array}{l}\operatorname{chi} 2(17)= \\
734.27 \\
(0.000) * * *\end{array}$ & $\begin{array}{l}\operatorname{chi} 2(18)= \\
950.37 \\
(0.000)^{* * *}\end{array}$ \\
\hline Sargan Test & & & & & & & $\begin{array}{l}\operatorname{chi} 2(32)= \\
40.10(0.154)\end{array}$ & $\begin{array}{l}\operatorname{chi} 2(32)= \\
40.51(0.144)\end{array}$ & $\begin{array}{l}\operatorname{chi} 2(32)= \\
41.23(0.127)\end{array}$ \\
\hline $\begin{array}{l}\text { Arellano-Bond test } \\
\text { for } \operatorname{AR}(1)\end{array}$ & & & & & & & $\begin{array}{l}\mathrm{N}(0,1)= \\
-3.327 \\
(0.001)^{* * *}\end{array}$ & $\begin{array}{l}\mathrm{N}(0,1)= \\
-3.497 \\
(0.000) * * *\end{array}$ & $\begin{array}{l}\mathrm{N}(0,1)= \\
-3.392 \\
(0.001)^{* * *}\end{array}$ \\
\hline $\begin{array}{l}\text { Arellano-Bond test } \\
\text { for } \operatorname{AR}(2)\end{array}$ & & & & & & & $\begin{array}{l}\mathrm{N}(0,1)= \\
-0.067 \\
(0.947)\end{array}$ & $\begin{array}{l}\mathrm{N}(0,1)=- \\
1.006(0.314)\end{array}$ & $\begin{array}{l}\mathrm{N}(0,1)= \\
-0.071 \\
(0.943)\end{array}$ \\
\hline
\end{tabular}

